\title{
Degradation of cyanotoxins (microcystin) in drinking water using photoelectrooxidation
}

\author{
Garcia, ACA. ${ }^{a}$, Rodrigues, MAS. ${ }^{b *}$, Xavier, JLN. ${ }^{a}$, \\ Gazulla, $V^{a}{ }^{a}$, Meneguzzi, $A{ }^{a}{ }^{a}$ and Bernardes, $A M^{a}{ }^{a}$ \\ ${ }^{a}$ Laboratório de Corrosão, Proteção e Reciclagem de Materiais, Universidade Federal do Rio Grande do Sul, \\ Avenida Bento Gonçalves, 9500, setor 4, prédio 74, CEP 91.501- 970, Porto Alegre, RS, Brazil \\ bUniversidade Feevale, RS 239, 2755, CEP 93.352-000, Novo Hamburgo, RS, Brazil \\ *e-mail: marcor@feevale.br
}

Received: May 24, 2013 - Accepted: August 20, 2013 - Distributed: May 31, 2015

(With 1 figure)

\begin{abstract}
The discharge of sewage and industrial effluents containing high concentrations of pollutants in water bodies increases eutrophication. Cyanobacteria, some of the organisms whose growth is promoted by high nutrient concentrations, are resistant and produce several types of toxins, known as cyanotoxins, highly harmful to human beings. Current water treatment systems for the public water supply are not efficient in degradation of toxins. Advanced oxidation processes (AOP) have been tested for the removal of cyanotoxins, and the results have been positive. This study examines the application of photoelectrooxidation in the degradation of cyanotoxins (microcystins). The performance of the oxidative processes involved was evaluated separately: Photocatalysis, Electrolysis and Photoelectrooxidation. Results showed that the electrical current and UV radiation were directly associated with toxin degradation. The PEO system is efficient in removing cyanotoxins, and the reduction rate reached $99 \%$. The final concentration of toxin was less than $1 \mu \mathrm{g} / \mathrm{L}$ of microcystin in the treated solution.
\end{abstract}

Keywords: microcystin, cyanotoxin, advanced oxidation process, photoelectrooxidation.

\section{Degradação de cianotoxinas (microcistinas) em água potável aplicando fotoeletrooxidação}

\begin{abstract}
Resumo
A descarga de esgotos e efluentes industriais contendo altas concentrações de poluentes nos corpos d'água aumenta a eutrofização. As cianobactérias, são organismos cujo crescimento é promovido por concentrações elevadas de nutrientes, são resistentes e produzem vários tipos de toxinas conhecidas, como cianotoxinas, altamente prejudiciais para os seres humanos. Os sistemas atuais de tratamento de água para o abastecimento público de água não são eficientes na degradação destas toxinas. Processos oxidativos avançados (POA) foram testados para a remoção de cianotoxinas, e os resultados têm sido positivos. Este estudo avalia o processo de fotoeletrooxidação (FEO) na degradação de cianotoxinas (microcistinas). Foi avaliado o desempenho dos processos envolvidos separadamente: fotocatalisis, eletrólise e fotoeletrooxidação. Os resultados mostram que a potencia da radiação UV e da corrente elétrica estão diretamente associados com a degradação de toxinas. O sistema de FEO é eficiente na remoção de cianotoxinas e a redução foi de $99 \%$. A concentração final de toxina foi inferior a $1 \mathrm{~g} / \mathrm{L}$ de microcistina na solução tratada.
\end{abstract}

Palavras-chave: microcistina, cianotoxinas, processo de oxidação avançada, fotoeletrooxidação.

\section{Introduction}

The growing eutrophication of water bodies, a result of human activity, artificially enriches ecosystems. Chemical fertilizers and manure, treated or untreated urban sewage discharges, and agricultural and industrial effluents significantly increase the amounts of nutrients, which run out of control and produce blooms of algae, such as cyanobacteria (Lemes and Yunes, 2006). Cyanobacteria, also known as blue-green algae, are a family of single-celled

algae that proliferate in water bodies, such as ponds, lakes, reservoirs, and slow-moving streams when the water is warm and nutrients are available. Many cyanobacteria species produce a group of toxins known as microcystins, some of which are toxic.

The occurrence of cyanobacterial blooms and the presence of cyanotoxins in water samples from the Armando Ribeiro Gonçalves reservoir, located in the state of Rio 
Grande do Norte, in the semiarid region of northeastern Brazil was reported (by Costa et al. (2006). In the State of Rio Grande do Sul, southern Brazil, cyanobacterial blooms, particularly Microcystis aeruginosa, have been described in the Patos lagoon and its estuary at irregular time intervals in the last two decades (Yunes et al., 1996). The toxicity of these blooms reached lethal doses (LD50), from 22 to $250 \mathrm{mg} \cdot \mathrm{kg}^{-1}$ in tests with mice (Yunes et al., 1996). Several studies demonstrated the toxic effects of cyanobacteria on zooplankton organisms, particularly microcrustacean (DeMott et al., 1991). Tests with the juvenile pink shrimp, a very important economic fishing resource in the region of the Patos lagoon, showed that LD50 was $2.9 \mathrm{mg} \cdot \mathrm{mL}^{-1}$ (Minillo et al., 2000). The main toxic cyanobacteria genera are Anabaena, Aphanizomenon, Nodularia and Microcystis, which produce a hepatotoxin that is hazardous for human beings and responsible for animal deaths (Moreira et al., 2011). Microcystins are cyclic-heptapeptides, characterised by an unusual amino acid residue, which is affects the toxicity of the heptapeptide (Almeida et al., 2006).

Toxic cyanobacterial blooms and the lack of efficient water treatment systems to remove cells and toxins produced by cyanobacteria may result in environmental catastrophes. In 1996, in Caruaru, in the Brazilian state of Pernambuco, signs and symptoms of acute neurotoxicity and sub-acute hepatotoxicity were detected in patients of a hemodialysis clinic. All 126 patients developed those symptoms, and 60 died (Pouria et al., 1998).

The toxins dissolved in water are not removed by conventional water treatment. In 1988, the World Health Organization (WHO) issued a consumption guideline of $1 \mu \mathrm{g}$ of LR-microcystin $\mathrm{L}^{-1}$. day ${ }^{-1}$ in treated drinking water. This limit in treated drinking water has been globally accepted. Brazil included this limit in legislation in 2004 (Almeida et al., 2006). In this scenario, several techniques have been developed to remove cyanobacterial cells and to degrade cyanotoxins. Oxidation with potassium permanganate removes microcystin and eliminates its toxicity. This process, however, depends on dose and contact time. In the presence of live cyanobacterial cells, the removal of soluble toxins is low. No consensus has been reached about whether potassium permanganate causes cyanobacterial lysis (Lam et al., 1995; Rositano et al., 1998; Hrudey et al., 1999). Activated coal adsorption has been shown to be effective in removing cyanotoxins (Falconer et al., 1989; Donati et al., 1994; Drikas et al., 2001). However, decontamination takes place by pollutant adsorption, and the pollutant is transferred from the liquid to the solid matter; that means that there is only transference of the pollutant phases, but no destruction (Ziolli and Jardim, 1998). Mondardo et al. (2006) tested ozonisation and chlorination to remove cyanobacteria. Ozonisation proved to be an excellent option for the pretreatment of water with high concentrations of micro-algae and cyanobacteria. It uses a direct filtration technique to make water potable and produces filtered water that matches the potability standards established by Norm 518 issued by the Brazilian Ministry of Health (Brasil, 2011). Mazur-Marzec et al. (2006) tested nodular degradation of cyanotoxin exposed to UVA or UVB radiation for 48 hours. They found that UVB was more effective and produced a greater removal rate (73.3\%). Bourne et al. (2006) studied the degradation of microcystin-LR when exposed to a biofilm produced by the bacteria generated in a water body using a sand filter. Two days were necessary to remove $90 \%$ of all microcystin. Mesquita et al. (2006) tested the removal of microcystin-LR using a biologically-active activated coal

system, and removal was $100 \%$ in the first 10 days. After the $8^{\text {th }}$ day, the amount of cyanotoxins in the effluent increased. After the $50^{\text {th }}$ day and for one month, microcystin removal was detected again.

The removal efficiency of cyanotoxin degradation using chlorine depends on chlorine dose, contact time, and $\mathrm{pH}$ (Campinas et al, 2002). A more general problem of water chlorination lies in the production of trihalomethane. Chloroform is the compound that raises greater concern because it is believed to be carcinogenic and to have adverse effects on reproduction and development (Baird, 2002).

Advanced oxidation processes (AOP) have been widely used for the degradation of organic compounds (Xavier, 2006). They are based on the generation of hydroxyl radicals $(\mathrm{OH})$, which have a high oxidation power and may promote the degradation of several pollutant compounds in a few minutes (Freire et al., 2000). A large variety of toxic organic compounds may be degraded using AOP; in most cases, degradation leads to full mineralization and generates $\mathrm{H}_{2} \mathrm{O}$ and $\mathrm{CO}_{2}$. Some classes of compounds that may be degraded are alkanes, chloroaliphatic compounds, alcohols, carboxylic acids, phenols, chlorophenols, herbicides, surfactants and dyes (Nogueira and Jardim, 1998).

Shephard et al. (1998) studied the effect of photocatalytic degradation of microcystin using $\mathrm{UV}$ radiation and $\mathrm{TiO}_{2}$. Microcystin concentration fell to $11 \%$ in about 15 minutes. It took 4 minutes for microcystin to reach levels below the test detection limit when a $1 \mathrm{~g} / 1$ concentration of $\mathrm{TiO}_{2}$ was used.

Photoelectrooxidation (PEO) is an AOP that uses only two reagents: photons and electrons. PEO is the combination of two other AOPs: electrolysis and heterogeneous photocatalysis (Pelegrini et al., 2001). This study evaluated the use of PEO in the degradation of cyanotoxins from Microcystis aeruginosa.

\section{Material and Methods}

\subsection{Cyanobacterial culture}

The cyanobacterial sample in this study consisted of Microcystis aeruginosa (strain NPLJ-4) isolated from the Jacarepaguá lagoon, in the state of Rio de Janeiro, Brazil, and supplied by the Laboratory of Ecophysiology and Toxicology of Cyanobacteria, Carlos Chagas Filho Institute of Biophysics, Federal University of Rio de Janeiro, and cultivated in ASM-1 growth medium (Gorham et al., 1964) in the Institute of Hydraulic Research of the Universidade Federal do Rio Grande do Sul (IPH-UFRGS). This toxic strain (NPLJ-4) was batch-cultured in $250 \mathrm{~mL}$ Erlenmeyer 
flasks in an incubator at $25^{\circ} \mathrm{C}$ with a $14: 10 \mathrm{~h}$ light dark cycle and light intensity of 2000 lux. When it reached a phase of exponential cell growth of $10^{7}$, the culture was frozen and thawed three times to promote cell lysis. The solution used in the degradation experiments was prepared by mixing $100 \mathrm{~mL}$ of concentrate NPLJ-4 crude extract with $1200 \mathrm{~mL}$ of water.

\subsection{The experiments}

The system used in the tests, developed by Rodrigues et. al. (2008) was composed of an electrochemical cell (Figure 1). Reactor volume was $1.4 \mathrm{~L}$. Titanium-coated titanium and ruthenium oxide $\left(\mathrm{Ti}-70 \% \mathrm{TiO}_{2} / 30 \% \mathrm{RuO}_{2}\right)$ electrodes were used, and the glass bulb of a $250 \mathrm{~W}$ mercury-vapor lamp was replaced with a quartz tube to allow the passage of UV radiation; a source was used to apply the electric field. The solution under study was placed in the reactor. A thermostatic bath was used to keep the temperature at $25^{\circ} \mathrm{C}$. In the reactor, the electrodes were placed concentrically around the lamp, with the cathode outside and the anode inside because of the photoactivity of the electrode material.

The performance of the oxidative processes involved was evaluated separately:

\section{Coolant in}

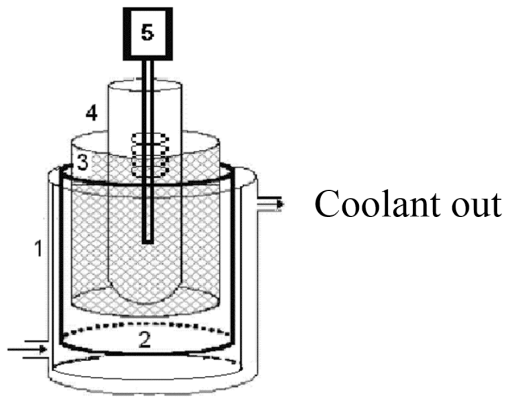

Figure 1. Reactor configuration: (1) glass jacket reservoir; (2) and (3) titanium-coated $\mathrm{TiO}_{2} / \mathrm{RuO}_{2}$ cathode and anode; (4) quartz tube; (5) mercury-vapor lamp.
- Photocatalysis (PC) - UV irradiation on the surface of the anode, without applying an electric current.

- Electrolysis (EL) - electric current, without UV radiation.

- Photoelectrooxidation (PEO) - electric current, combined with UV irradiation of the anode.

\subsection{Cyanotoxin analysis}

This study used a commercial enzyme-linked immunosorbent assay (ELISA Beacon ${ }^{\circledR}$ ) kit to measure microcystin concentration before and after the degradation trials. ELISA is an analytic biochemistry assay that uses a solid-phase enzyme immunoassay (EIA) to detect the presence of a substance, usually an antigen, in a liquid sample or wet sample. The test uses antibodies and color change to identify a substance.

\section{Results}

Table 1 describes experimental conditions and results of toxin degradation. Results of trials I-PEO, II-PEO and III-PEO, with $99 \%$ removal rates using currents of 4.0 , 2.0 and $1.0 \mathrm{~mA} / \mathrm{cm}^{2}$, indicated that excellent degradation rates are achieved for all current densities used. Even when low current densities were used $\left(1.0 \mathrm{~mA} / \mathrm{cm}^{2}\right)$, cyanotoxin concentrations after treatment was $0.3 \mu \mathrm{g} . \mathrm{L}^{-1}$, a value below the limits established in international legislation. For solutions with a low electrical conductivity, supporting electrodes should be used to reduce system resistance. In this study, sodium chloride was chosen as the supporting electrolyte, because it forms oxidant compounds, in addition to reducing system resistance still during oxidations, which contributes to toxin degradation. However, the comparison of PEO III and IV results revealed that, even in the absence of sodium chloride, cyanotoxin concentration is below the accepted limit after treatment.

However, when current was not added (PC experiments) and UV radiation was not used (EL experiments), there was a great reduction of the removal rate, from

Table 1. Experimental conditions and results of toxin degradation.

\begin{tabular}{|c|c|c|c|c|c|c|}
\hline \multirow{2}{*}{ Trials } & \multicolumn{4}{|c|}{ Photoelectrooxidation Trials } & \multirow{2}{*}{$\begin{array}{c}\text { Electrolysis } \\
\text { Trial }\end{array}$} & \multirow{2}{*}{$\begin{array}{c}\begin{array}{c}\text { Photocatalysi } \\
\text { Trial }\end{array} \\
\text { PC }\end{array}$} \\
\hline & I-PEO & II-PEO & III-PEO & IV-PEO & & \\
\hline \multicolumn{7}{|l|}{ Parameters } \\
\hline Time $[\mathrm{min}]$ & 10 & 10 & 10 & 10 & 10 & 10 \\
\hline Current density $\left[\mathrm{mA} / \mathrm{cm}^{2}\right]$ & 4.0 & 2.0 & 1.0 & 1.0 & 1.0 & No \\
\hline $\mathrm{NaCl}[4 \mathrm{~g} / \mathrm{L}]$ & Yes & Yes & Yes & No & No & No \\
\hline UV radiation & Yes & Yes & Yes & Yes & No & No \\
\hline Initial microcystin $\left[\mu \mathrm{gL}^{-1}\right]$ & 6.91 & 6.91 & 6.91 & 6.91 & 6.91 & 6.91 \\
\hline Final microcystin $\left[\mu \mathrm{gL}^{-1}\right]$ & $<0.3^{*}$ & $<0.3 *$ & $<0.3^{*}$ & $<0.3^{*}$ & 3.49 & 3.12 \\
\hline Removal rate [\%] & $99 \%$ & $99 \%$ & $99 \%$ & $99 \%$ & $49 \%$ & $41 \%$ \\
\hline
\end{tabular}

*ELISA Beacon ${ }^{\circledR}$ detection limit. 
$99 \%$ to $41 \%$ and $49 \%$. In these experiments, cyanotoxin concentration after treatment had values above legal limits. These results suggest that, in PEO experiments, there was an interaction between UV radiation and electrical current, which cause a greater toxin degradation due to a synergistic effect on microcystin degradation.

\section{Conclusions}

This study found that the photoelectrooxidation system under test was effective for the degradation of cyanotoxins. Electrical current and UV radiation were directly associated with toxin degradation. The analysis of the application of UV radiation revealed an improvement in the performance of the microcystin degradation process, and confirmed the synergistic effect of combined oxidative processes. Results confirmed that the use of a supporting electrolyte was not necessary for degradation. Photoelectrooxidation, as investigated in this study, seems to be a promising process for the treatment of public supply waters.

\section{References}

ALMEIDA, VPS., COGO, K., TSAI, SM. and MOON, DH., 2006. Colorimetric test for the monitoring of microcystins in cyanobacterial culture and environmental samples from southeast - Brazil. Brazilian Journal of Microbiology, vol. 37, no. 2, p. 192-198. http://dx.doi.org/10.1590/S1517-83822006000200017.

BAIRD, C., 2002. Química Ambiental. 2nd ed. Porto Alegre: Bookman. 622 p.

BOURNE, DG., BLAKELEY, RL., RIDDLES, P. and JONES, GJ., 2006. Biodegradation of the cyanobacterial toxin microcystin LR in natural water and biologically active slow sand filters. Water Research, vol. 40, no. 6, p. 1294-1302. http://dx.doi.org/10.1016/j. watres.2006.01.022. PMid:16516264.

Brasil. Ministério da Saúde, 2011. Portaria 2914 de 12 de dezembro de 2011. Estabelece procedimentos e responsabilidades relativos ao controle e vigilância da qualidade da água para consumo humano e seu padrão de potabilidade, e das outras providências. Diário Oficial da União, Brasília, 26 dec. Seção I, n. ${ }^{\circ}$ 63, p. 166.

CAMPINAS, M., TEIXEIRA, MR., LUCAS, H. and ROSA, MJ., 2002. Previsão da capacidade de remoção de cianobactérias e cianotoxinas na ETA de Alcantarilha. In Actas do $10^{\circ}$ Encontro Nacional de Saneamento Básico, 2002. Braga. Braga: Associação Portuguesa de Saneamento Básico.

COSTA, IAS., AZEVEDO, SMFO., SENNA, PAC., BERNARDO, RR., COSTA, SM. and CHELLAPPA, NT., 2006. Occurrence of toxin-producing cyanobacteria blooms in a Brazilian semiarid reservoir. Brazilian Journal of Biology = Revista Brasileira de Biologia, vol. 66, no. 1b, p. 211-219. http://dx.doi.org/10.1590/ S1519-69842006000200005. PMid:16710515.

DEMOTT, WR., ZHANG, Q. and CARMICHAEL, WW., 1991. Effects of toxic cyanobacteria and purified toxins on the survival and feeding of a copepod and three species of Daphnia. Limnology and Oceanography, vol. 36, no. 7, p. 1346-1357. http://dx.doi. org/10.4319/lo.1991.36.7.1346.

DONATI, C., DRIKAS, M., HAYES, KR. and NEWCOMBE, G., 1994. Microcystin-LR adsorption by powdered activated carbon. Water Research, vol. 28, no. 8, p. 1735-1742. http:// dx.doi.org/10.1016/0043-1354(94)90245-3.

DRIKAS M, CHOW, CWK., HOUSE, J. and BURCH, MD., 2001. Using coagulation, flocculation and settling to remove toxic cyanobacteria. Journal - American Water Works Association, vol. 93, no. 2, p. 100-111.

FALCONER, IR., RUNNEGAR, MTC., BUCKLEY, T., HUYN, VL. and BRADSHAW, P., 1989. Using activated carbon to remove toxic cyanobacteria. Journal - American Water Works Association, vol. 81 , no. 2 , p. $102-105$

FREIRE, RS., PELEGRINI, R., KUBOTA, LT., DURAN, N. and PERALTA-ZAMORA, P., 2000. Novas tendências para o tratamento de resíduos industriais contendo espécies organocloradas. Quimica Nova, vol. 23, no. 4, p. 504-511. http://dx.doi.org/10.1590/S010040422000000400013

GORHAM, PR., MCLACHLAN, J., HARMER, UTE. and KIM, WH., 1964. Isolation and culture of toxic strains of Anabaena flos-aquae (Lingb.). Verhandlungen des Internationalen Verein Limnologie. (15): 769-780.

HRUDEY, SE., BURCH, M., DRIKAS, M. and GREGORY, R., 1999. Remedial measures. In CHORUS, I. and e BARTRAM, J. (Eds.). Toxic Cyanobacteria in Water. London: WHO.

LAM, AKY., PREPAS, EE., SPINK, D. and HRUDEY, SE., 1995. Chemical control of hepatotoxic phytoplankton blooms: implications for human health. Water Research, vol. 29, no. 8, p. 1845-1854. http://dx.doi.org/10.1016/0043-1354(94)00348-B.

LEMES, G. and YUNES, J., 2006. O meio ambiente e as cianobactérias. Ecos, vol. 25, p. 9-11.

MAZUR-MARZEC, H., MERILUOTO, J. and PLIŃSKI, M., 2006. The degradation of the cyanobacterial hepatotoxin nodularin (NOD) by UV radiation. Chemosphere, vol. 65, no. 8, p. 13881395. http://dx.doi.org/10.1016/j.chemosphere.2006.03.072. PMid:16698064

MESQUITA, E., MENAIA, J., ROSA, MJ. and COSTA, V., 2006. Microcystin-LR removal by bench scale biological-activated-carbon filters. In. GIMBEL, R., GRAHAM, JD. and. COLLINS, MR. (Eds.). Recent Progress in Slow sand and Alternative Biofiltration Processes. London: IWA Publishing. p. 373.

MINILLO, A., FERREIRA, AHF., YOGUI, GT. and YUNES, JS., 2000. Concentrações de microcistinas e toxicidade nas formas coloniais de Microcystis Aeruginosa de florações no Estuário da Lagoa dos Patos, RS. In ESPÍNDOLA, ELG., BOTTA-PASCHOAL, CMR., ROCHA, O., BOHRER, MBC. and OLIVEIRA-NETO, AL. (Eds.). Ecotoxicologia: Perspectivas para o Século XXI. São Carlos: RiMa.

MONDARDO, RI., SENS, ML. and MELO FILHO, LC., 2006. Pré-tratamento com cloro e ozônio para remoção de cianobactérias. Revista Engenharia Sanitária e Ambiental, vol. 11, no. 4, p. 337-342.

MOREIRA, IC., BIANCHINI, I Jr. and VIEIRA, AAH., 2011. Decomposition of dissolved organic matter released by an isolate of Microcystis aeruginosa and morphological profile of the associated bacterial community. Brazilian Journal of Biology = Revista Brasileira de Biologia, vol. 71, no. 1, p. 57-63. http:// dx.doi.org/10.1590/S1519-69842011000100009. PMid:21437399.

NOGUEIRA, RFP. and JARDIM, WF., 1998. A fotocatálise heterogênea e sua aplicação ambiental. Quimica Nova, vol. 21, no. 1, p. 69-72. http://dx.doi.org/10.1590/S0100-40421998000100011. 
PELEGRINI, RT., FREIRE, RS., DURAN, N. and BERTAZZOLI, R., 2001. Photoassisted electrochemical degradation of organic pollutants on a DSA type oxide electrode: process test for a phenol synthetic solution and its application for the E1 bleach Kraft mill effluent. Environmental Science \& Technology, vol. 35, no. 13, p. 2849-2853. http://dx.doi.org/10.1021/es001784j. PMid:11452621.

POURIA, S., ANDRADE, A., BARBOSA, J., CAVALCANTI, RL., BARRETO, VTS., WARD, CJ., PREISER, W., POON, GK., NEILD, GH. and CODD, GA., 1998. Fatal microcystin intoxication in haemodialysis unit in Caruaru, Brazil. Lancet, vol. 352, no. 9121, p. 21-26. http://dx.doi.org/10.1016/S01406736(97)12285-1. PMid:9800741.

RODRIGUES, MAS., AMADO, FDR., XAVIER, JLN., STREIT, KF., BERNARDES, AM. and FERREIRA, JZ., 2008. Application of photoelectrochemical-electrodialysis treatment for the recovery and reuse of water from tannery effluents. Journal of Cleaner Production, vol. 16, no. 5, p. 605-611. http://dx.doi.org/10.1016/j. jclepro.2007.02.002.

ROSITANO, J., NICHOLSON, BC. and PIERONNE, P., 1998. Destruction of cyanobacterial toxins by ozone. Ozone Science and Engineering, vol. 20, no. 3, p. 223-238. http://dx.doi. org/10.1080/01919519808547273.

SHEPHARD, GS., STOCKENSTRÖM, S., DE VILLIERS, D., ENGELBRECHT, WJ., SYDENHAM, EW. and WESSELS, GF., 1998. Photocatalytic degradation of cyanobacterial microcystin toxins in water. Toxicon, vol. 36, no. 12, p. 1895-1901. http:// dx.doi.org/10.1016/S0041-0101(98)00110-X. PMid:9839673.

XAVIER, JLN., 2006. O uso da fotoeletrooxidação no tratamento de efluentes de curtumes. Porto Alegre: Universidade Federal do Rio Grande do Sul. Masters Dissertation in Engineering.

YUNES, JS., SALOMON, PS., MATTHIENSEN, A., BEATTIE, KA., RAGGETT, SL. and CODD, GA., 1996. Toxic blooms of cyanobacteria in Patos Lagoon Estuary, southern Brazil. Journal of Aquatic Ecosystem Health, vol. 5, no. 4, p. 223-229. http:// dx.doi.org/10.1007/BF00662183.

ZIOLLI, RL. and JARDIM, WF., 1998. Mecanismo de Fotodegradação de Compostos Orgânicos Catalisada por TiO2. Quimica Nova, vol. 21, no. 3, p. 319-325. http://dx.doi.org/10.1590/S010040421998000300013. 